Military Technical College Kobry El-Kobbah, Cairo, Egypt

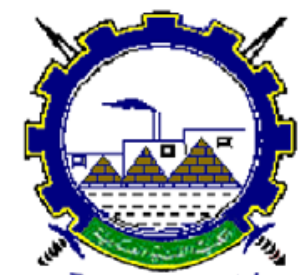

I.C.E.E.2014 $7^{\text {th }}$ International Conference on

Chemical \& Environmental Engineering

27 - 29 May, 2014.

\begin{tabular}{lll|}
\hline \multicolumn{1}{c}{ Chemical \& Environmental Engineering I } \\
(CEEA)
\end{tabular}




\author{
Military Technical College \\ Kobry El-Kobbah, \\ Cairo, Egypt
}

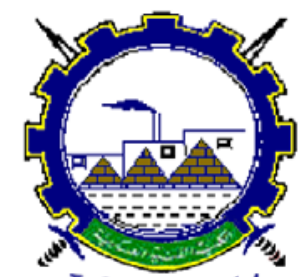

I.C.E.E.2014 $7^{\text {th }}$ International Conference

Chemical \& Environmental Engineering

27 - 29 May, 2014.

CEEA-3

\title{
Photochemical Studies and Dye Sensitized Solar Cell Based On 8-Hydroxyquinoline
}

\author{
K.A. Ali ${ }^{*}$ and M.S.A. Abdel-Mottaleb ${ }^{\dagger}$
}

\begin{abstract}
:
8-Hydroxyquinoline(HQ) is a monoprotic bidentate chelating agent, which forms a fluorescent complex with $\mathrm{AlCl}_{3}$ in the ground and the excited states. The formation constants are determined from the least squares fitting of Benesi-Hildebrand and Hill plots.

8-hydroxyquinoline and 8-hydroxyquinoline aluminum salt $\left(\mathrm{AlHQ}_{3}\right)$ show photostabilityin the presence of suspended $\mathrm{TiO}_{2}$ (Degaussa P25). The photostability of the surface complexes $\left(8-\mathrm{HQ}_{2}-\mathrm{TiO}_{2}\right)$ and $\left(\mathrm{AlHQ}_{3}-\mathrm{TiO}_{2}\right)$ has been examined in the presence of $\left(\mathrm{I}^{-} / \mathrm{I}_{2}\right)$ electrolyte solution showing a significant changes in the absorption and the fluorescence spectra of $\mathrm{AlHQ}_{3}$ and the rate of the reaction is determined.

The photostability results of 8-Hydroxyquinoline favor its exploitation as a sensitizer in dyesensitized solar cell (DSSC). Light into electricity conversion efficiency is calculated from the current -voltage (I-V) curve for 8-HQ sensitized solar cell.Although 8-HQ reveals an appreciatedphotostability, it is not an efficient dye for light to electricity conversion due to its limited light absorption range (290-340nm).
\end{abstract}

\section{Keywords:}

Photostability, Dye-sensitizedsolarcell, 8-HQ, 8-Hydroxyquinoline aluminum salt

\footnotetext{
Chemistry Administration, karima_ali_7@yahoo.com

$\dagger$ NanoPhotochemistry and Solar Chemistry Lab, Department of Chemistry, Faculty of Science, Ain Shams University,

Abbassia, 11566 Cairo, Egypt, greener09@photoenergy.org
} 


\section{1-Introduction}

8-Hydroxyqunolie is well known to react as a chelating agent with several metal ions because of the presence of basic nitrogen, and a phenolic group in its structure, (Fig.1). 8-HQ is nonfluorescent and sometimes it displays very weak fluorescence due to the intramol-

ecular proton transfer process (from oxygen to nitrogen) in its excited state, which provides a route for non-radiative relaxation [1,2]. Once this proton is lost, 8-HQ becomes highly fluorescent[1,3]. Consequently, this unique 8-HQ property can provide an on-off sensing response to metal ion binding.

Application of $\mathrm{TiO}_{2}$ in photocatalyst processes is based on its remarkable activity, chemical stability and also on its non-toxic-properties. However, only light of wavelengths below $400 \mathrm{~nm}$ can be absorbed by $\mathrm{TiO}_{2}$ particles to generate $\mathrm{e}^{-} / \mathrm{h}^{+}$pairs [19]. It is known that less than about 5\% of the solar energy reaching the surface of the earth is ultraviolet light [4]. $\mathrm{TiO}_{2}$ (Degussa P25) is one of the most photochemically active commercial forms of $\mathrm{TiO}_{2}$, which consists of about $70 \%$ anatase and $30 \%$ rutile [5].

The dye-sensitized solar cell (DSSC) is a device for the conversion of visible light into electricity based on the sensitization of wide band gap of semiconductors $[6,7,8]$.

The performance of the cell mainly depends on the dye used as sensitizer. The absorption spectrum of the dye and the anchorage of the dye to the surface of $\mathrm{TiO}_{2}$ are important parameters determining the efficiency of the cell $[6,9]$.

Research on organometallic complexes has attracted scientific and commercial attention due to their promising applications in organic devices such as organic light emitting diode (OLED) and organic solar cells. $\mathrm{AlHQ}_{3}$ is the most common organometallic complex that has been widely studied as organic semiconductor many years ago. This is because $\mathrm{AlHQ}_{3}$ possesses a very good luminescent efficiency, which emits in the green spectral region with a broad emission peak at about $525 \mathrm{~nm}$, high electron mobility and thermal stability. Due to this fact, $\mathrm{AlHQ}_{3}$ has been so far one of the best electron transport material and emission material that is used in multilayer OLED [18].

The paper is focusing on the formation of the complex $\mathrm{AlHQ}_{3}$ in the ground state and the excited state and the calculation of the formation constants using Benesi-Hildebrand and Hill plots. The photostability of the surface complexes $\left(8-\mathrm{HQ}_{-} \mathrm{TiO}_{2}\right)$ and $\left(\mathrm{AlHQ}_{3}-\mathrm{TiO}_{2}\right)$ is examined in the presence of redox couple $\left({\overline{\mathrm{I}_{3}}}_{3}^{-}\right)$for possible use as sensitizers for nanocrystalline solar cell. A dye-sensitized solar cell based of 8-HQ is fabricated and its conversion efficiency will be evaluated.

\section{2-Experimental}

\subsection{Chemicals}

8-Hydroxyquinoline was obtained from Sigma. Aluminium chloride and iodine were obtained from Merck company . Ethanol absolute (Riedel) for HPLC measurements.Potassium iodide was obtained from Fluka Company.The $\mathrm{TiO}_{2}$ fine powder (Degaussa P25), which is a 70:30 mixture of anatase : rutile from Deguassa- HülsCompany.Titanium (IV) isopropoxide was obtained from Aldrich. Stannous chloride AR was obtained form S.D. FIN-CHEM 
LTD.Antimony trioxide was obtained from B.D.H. England.Ethylene glycol was obtained from B.H.E. England. All the chemicals were used as received.

\subsection{Instrumentation}

The absorption spectra were recorded using Helios \& Unicamspectrophotometer. Fluorescence measurements were recorded using RF 5301 PC Shimadzuspectrofluorometer.The photostability setup consistedof an irradiation source of 150W Xenon arc lamp with a wavelength range (190-900nm)from Photon technology international company. The power of the lamp was adjusted at $70 \mathrm{~W}$ during the photostabilty tests.The light intensity was measured using radiometer (IL1700 International Light).The photochemical reactor was a cylindrical

Double-walled quartz cell with inlet and outlet for cooling by water to maintain the temperature constant at $\left(22 \pm 0.2^{\circ} \mathrm{C}\right)$.

\subsection{Fabrication of dye-sensitized solar cell (DSSC)}

A thin film of conducting $\mathrm{SnO}_{2}$ doped with antimony trioxide on a commercially glass plate was used for the starting material for the electrodes, [12].The surface resistivity was measured using an avometer (model Keithley 2635, USA) with current-voltage ranges (20fA-1.5A) and $(1 \mu \mathrm{V}-202 \mathrm{~V})$. The glass plates, coated with a thin film of nanocrystalline $\mathrm{TiO}_{2}$ were soaked in an ethanolicsolution of 8-HQ forming asurface complex capable of electron injection.

Applying a thin carbon film on another piece of conductive glass plate made the counter electrode.The two opposing glass plates were offset so thatthe counter electrode covered all of the $\mathrm{TiO}_{2}$. One or two drops of $\left(\mathrm{KI} / \mathrm{I}_{2}\right)$ electrolyte solution were placed at the edges of the plates.Light should enter the glass sandwich through the $\mathrm{TiO}_{2}$ coated glass plate. Currentvoltage [I-V]curve for the cell was plotted from which the conversion efficiency of sunlight to electrical energy is calculated.

\subsection{Data analysis}

The formation constant is estimated from the changes in both absorbance and fluorescence intensities froma Benesi-Hildebrand plot, equation (1),[10,11].

$$
\frac{1}{\mathrm{~A}_{\mathrm{obs}}-\mathrm{A}_{\circ}}=\frac{1}{\mathrm{~A}_{\mathrm{C}}-\mathrm{A}_{\circ}}+\frac{1}{\mathrm{~K}_{\text {formation }}\left(\mathrm{A}_{\mathrm{C}}-\mathrm{A}_{\circ}\right)\left[A \mathrm{l}^{3+}\right]}
$$

Where $\mathrm{A}_{\mathrm{obs}}$ is the absorbance of 8-HQ solution containing of different concentrations of $\mathrm{Al}^{3+}$ ions. $\mathrm{A} \circ$ and $\mathrm{Ac}$ are the absorbances of $8-\mathrm{HQ}$ and the complex $\mathrm{Alq}_{3}$ respectively.Therefore, $\mathrm{A}$ plot of $\frac{1}{\mathrm{~A}_{\mathrm{obs}}-\mathrm{A}_{\circ}}$ versus $\frac{1}{\left[A l^{3+}\right]}$ should yield alinear relationship with a slope equal to $\frac{1}{\mathrm{~K}_{\text {formation }}\left(\mathrm{A}_{\mathrm{C}}-\mathrm{A}_{\circ}\right)}$ and the intercept equals $\frac{1}{\mathrm{~A}_{\mathrm{C}}-\mathrm{A}_{\circ}}$. From the slope and the intercept, we obtain $\mathrm{k}_{\text {formation }}$

The apparent association constant $\left(\mathrm{K}_{\mathrm{app}}\right)$ in the formation of the surface complex $\left(8 \mathrm{HQ}-\mathrm{TiO}_{2}\right)$ is determined from the plot $\frac{1}{\mathrm{~A}_{\mathrm{obs}}-\mathrm{A}_{\circ}}$ versus $\frac{1}{\left[\mathrm{TiO}_{2}\right]}$, equation (2).

$$
\frac{1}{\mathrm{~A}_{\mathrm{obs}}-\mathrm{A}_{\circ}}=\frac{1}{\mathrm{~A}_{\mathrm{C}}-\mathrm{A}_{\circ}}+\frac{1}{\mathrm{~K}_{\mathrm{app}}\left(\mathrm{A}_{\mathrm{C}}-\mathrm{A}_{\circ}\right)\left[T i \mathrm{O}_{2}\right]}
$$


For the fluorescence data, $\mathrm{K}_{\text {formation }}$ of $\mathrm{AlHQ}_{3}$ complex can be estimated from equation (3)

$$
\frac{1}{I_{\text {obs }}-I_{\circ}}=\frac{1}{A_{C}-A_{\circ}}+\frac{1}{K_{\text {formation }}\left(I_{C}-I_{\circ}\right)\left[A l^{3+}\right]}
$$

The plot of $\frac{1}{\mathrm{I}_{\mathrm{obs}} \mathrm{I}_{\circ}}$ versus $\frac{1}{\left[A l^{3+}\right]}$ should yield a linear relationship with a slope equal to $\frac{1}{\mathrm{~K}_{\text {formation }}\left(\mathrm{I}_{\mathrm{C}}-\mathrm{I}_{\circ}\right)}$ and the intercept equals $\frac{1}{\mathrm{I}_{\mathrm{C}}-\mathrm{I}_{\circ}}$. From the slope and the intercept, we obtain $\mathrm{K}_{\text {formation. }}$.

The rate constant of the photostability test for the surface complex $\left(\mathrm{AlHQ}_{3}-\mathrm{TiO}_{2}\right)$ in presence of $\left(\mathrm{I}^{-} / \mathrm{I}_{2}\right)$ electrolyte solution in both the ground state and the excited state are defined by equations, (4 and 5).

$$
\begin{aligned}
& \ln \frac{A_{\circ}}{A_{t}}=k T \\
& \ln \frac{I_{\circ}}{I_{t}}=K T
\end{aligned}
$$

Where $A_{0} / I_{0}$ is the (absorbance / fluorescence) intensity before irradiation and $\left(A_{t} / I_{t}\right)$ is the (absorbance / fluorescence) intensity at different time intervals. Aplot of left term against time gives a straight line, the slope of which is the rate constant of the reaction [12]. When there is an increase in both absorbance and florescence intensities on continued exposure of the samplesto radiation, the rate constant in determined from equations(6 and 7).

$$
\begin{aligned}
& \ln \frac{A_{f}}{A_{f}-A_{s}}=K T \\
& \ln \frac{I_{f}}{I_{f}-I_{s}}=K T
\end{aligned}
$$

The plot of the left term versus time gives a straight line, the slope of which is the rate constant of the reaction.

The conversion efficiency of sunlight to electrical energy is calculated from the equation (8)

$$
\% \text { efficiency }=\frac{\text { maximum output power }}{\text { input power }}
$$

$\overline{\text { incident light int ensity } \mathrm{x} \text { area of the active layer }}$

$\mathrm{I}_{\mathrm{m}}$ : Maximum current output

$\mathrm{V}_{\mathrm{m}}$ : Maximum voltage output

\section{3-Results and Discussion}

\subsection{Spectroscopic properties of 8-HQ}

8-HQ is a conjugated system and at the same time a bifunctional hydrogen bonding molecule, which in protic solvents simultaneously acts as an $\mathrm{H}$ donor via its acidic $\mathrm{O}-\mathrm{H}$ group and as a protic acceptor at the basic $\mathrm{N}$ atom. 
The absorption spectrum of 8-HQ in ethanol shows an absorption peak at 312nm. This result can provide relevant information about a specific solute-solvent association such as hydrogen bonding or an electron donor-acceptor interactions [14].The lack of the fluorescence intensity of 8-HQ inethanolis attributed to an intramolecular proton transfer process in the excited state, which provides a route for non-radiative relaxation [1,2].

\subsection{Complex formation between 8-HQ and $\mathrm{AlCl}_{3}$}

\section{In the ground state}

Different portions of a stock solution of $\mathrm{AlCl}_{3}, 10^{-3} \mathrm{M}$, are transferred into a number of $10-\mathrm{ml}$ volumetric flasks each containing $1.0 \mathrm{ml}$ of $8-\mathrm{HQ}$ solution, $10^{-3} \mathrm{M}$, and diluted with ethanol. The absorption band of 8-HQ of wavelength 312nm undergoes a noticeable disappearance and at the same time a new absorption peakis shown at longer wavelength $(365 \mathrm{~nm})$ as the concentration of $\mathrm{Al}^{3+}$ ions increases and an isosbestic point appears at $340 \mathrm{~nm}$. These results suggest the formation of a chelating complex between 8-HQ and of $\mathrm{Al}^{3+}$ ions( $\mathrm{AlHQ}_{3}$ ), (Fig.3).

\section{In the excited state}

The fluorescence spectrum due to the reaction between 8-HQ and $\mathrm{AlCl}_{3}$ is obtained by exciting into the formed complex absorption peak at 340nm. The fluorescence intensity increases as the concentration of $\mathrm{Al}^{3+}$ ions increases. It is a fluorescent complex because the non-bonded electrons in 8-HQ bind to $\mathrm{Al}^{3+}$ ions forming a ring which increases the rigidity of the molecule, (Fig. 4),[15].

In $\mathrm{AlHQ}_{3}$, the $\mathrm{Al}^{3+}$ ions stabilize the MOs of oxygen that carries most of the negative charge of the ligand. The nitrogen-aluminum interaction is relatively weak, (Fig.2),[16].

The formation constant values of the formed complex $\left(\mathrm{AlHQ}_{3}\right)$ in the ground state and the excited state are estimated from a Benesi-Hilde brand and Hill plots.

\subsection{Effect of irradiation on the surface complexesin the ground state and the excited state}

\section{In absence of $\left(\mathrm{KI} / \mathrm{I}_{2}\right)$ solution}

$100 \mathrm{ml}$ of ethanlic solutions of 8-HQ/AlHQ 3 are illuminated with Xe arc lamp in a water cooled reactor with continuous stirring for $1 \mathrm{hr}$ in the presence of suspended $\mathrm{TiO}_{2}$ (Degaussa P25)and absorbance / fluoresecne measurements are recorded at different time intervals. Both surface complexes $\left(8-\mathrm{HQ}_{-} \mathrm{TiO}_{2}\right)$ and $\left(\mathrm{AlHQ}_{3}-\mathrm{TiO}_{2}\right)$ show a photostability upon $1 \mathrm{hr}$ of illumination.

\section{In the presence of $\left(\mathrm{KI} / \mathrm{I}_{2}\right)$ solution}

When the surface complexes are illuminated in the presence of $\left(\mathrm{I}^{-} / \mathrm{I}_{2}\right)$ electrolyte solution for 1hr, no significant changes in the absorption spectrum neither the fluorescence spectrum of the surface complex $\left(8-\mathrm{HQ}_{-}-\mathrm{TiO}_{2}\right)$ are observed indicating a high photostability of $8-\mathrm{HQ}$ which implies no interaction between $8-\mathrm{HQ}$ and $\left(\mathrm{I}^{-} / \mathrm{I}_{2}\right)$ electrolyte solution, but a steady decrease in the absorption spectrum of $\left(\mathrm{AlHQ}_{3}-\mathrm{TiO}_{2}\right)$ and an increase is observed in the fluorescence intensity of $\left(\mathrm{AlHQ}_{3}-\mathrm{TiO}_{2}\right)$, due to the interaction between $\mathrm{AlHQ}_{3}$ and iodide ions that may form a complex with $\mathrm{Al}^{3+}$ ions or a mixed complex with $\mathrm{AlHQ}_{3}$ [17].The resultsaretreated and therate constants of the reactions are calculated,(Fig. 5). 


\subsection{Fabrication of dye-sensitized solar cell based on 8-HQ}

\section{Effect of colloidal solution of $\mathrm{TiO}_{2}$ on the absorption spectrum of 8-HQ}

The effect of increasing $\mathrm{TiO}_{2}$ concentration on the absorption spectrum of 8-HQ, (Fig. 6) shows an increase in the absorbance and slight amount of red shift in the absorption spectrum of 8-HQ. It reveals aninteraction between the nanoparticles of $\mathrm{TiO}_{2}$ and 8-HQdue to a chemisorptions between 8-HQ and $\mathrm{TiO}_{2}$ through a phenolic group $(\mathrm{OH})$ and $\mathrm{TiO}_{2}$. The association constant is estimated from the changes in absorbance intensity from a BenesiHildebrand plot at different $\mathrm{TiO}_{2}$ concentrations.

\section{I-V characterization of dye sensitized solar cell}

$\mathrm{I}-\mathrm{V}$ plot for DSSC of active area $0.5 \mathrm{~cm}^{2}$ is shown in the figure. The maximum product of current and voltage (obtained near the "knee" of the curve) is divided by the incoming light power to obtain the conversion efficiency of light energy, (Fig. 7), which is around $0.015 \%$ for 8-HQ sensitized solar cell.

\section{4-Conclusion}

8-Hydroxyquinoline forms a fluorescent complex $\mathrm{AlHQ}_{3}$ in ethanol and the photostability studies favors 8-HQ exploitation as a sensitizer in DSSC. The fabricated DSSC showed low conversion efficiency $(0.015 \%)$ due to its limited absorption range.

\section{5-References}

[1] Zukih,M.; Ultra Chemistry, 8(3), 2012, pp.377-385.

[2] Fernandez, J. L.; Nunez, C.; Faza, O. N.; InorganicaChimicaActa,381, 2012, pp. 218.

[3] Pondi, L.; Montalti, M.; Zaccheroni, N.; J.Inclusion Phenom, 41, 2001, pp.123.

[4] Zielinska, B.; Grzechuls, J.; Morawski, A. W.; Journal of Photochemistry and Photobiol-ogy A: Chemistry, 157, 2003, pp.65-70.

[5] Masakazu, A.; Prashant, V.K.; Environmentally Benign Photocatalyst: Applications of titanium oxide-based materials, springer, 2010, pp.160.

[6] Abdou, E. M.; Hafez, H. S.; AbdelMottaleb, M. S. A.; Spectrochemica Acta A: Molecular and Biomolecular Spectroscopy, 115, 2013, pp.202-207.

[7] Cherepy, N. J.; Smestad, G. P.; Grätzel, J. Z.; J. Phys. Chem. B, 101, 1997, pp.93429351

[8] Grätzel, J. Z.; J. Photochem.Photobiol., C4, 2000, pp.145-153.

[9] Tennakone, K.; kumara, A. R.; Sirimannne, P. M.; J. Photochem. Photobiol. A, 94, 1996, pp.217-220.

[10] He, J.; Zhao, J.; shen, T.; serpone, N.; J. Phys. Chem. B, 101, 1997, 9027.

[11] Ramakrishna, G.; Gohosh, H. N.; J.Phys. Chem. B, 105, 2001, pp.7000.

[12] Yang, S.; tian, H.; Xiao, H.; Gong, X.; Yao, S.; Chen, K.; Dyes and Pigments, 94, 2001, pp.93

[13] Smestad, G.; Grätzel, M.; J. Chem Edu, 75, 1998, pp.752-756.

[14] Elena, M. F.; Ionel, V. H.; Constantin, I. G.; Acta Chemica lasi, 7, 2009, pp.85-96.

[15] Brian, W.; Principles and Applications of Photochemistry, John Willey \& Sons, 2009,pp.69-70.

[16] Anita, S.; Devender, S.; Partaps, S. K. Amit, K.; Kapoor, S.; Gayatri, C.; Ishwar, S.; Ind-ian Journal of Chemistry, 49A, 2010, pp.448-451.

[17] Cotton, F. A.; Wilkinson, G.; Advanced Inorganic Chemistry, Interscience Publishers, 1999, pp.503-520. 
[18] Za’abra, N. K.; Mohd Sarjidan, M. A.; Basri, S. H.; Abd Majid, W. H.; Journal of Nanoe-lectronics and Optoelectronics, 8, 2013, pp.1-9.

[19] Akira, F.; Tatan, R.; Donald, A.; Gournal of photochemistry and photobiology C: Photochemistry Review S1, 2000, pp. 1-21.<smiles>Oc1cccc2cccnc12</smiles>

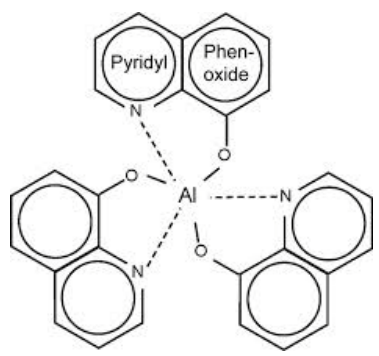

Fig.1. The molecular structure of 8-Hydroxyquinoline

Fig. 2. The molecular structure of 8-hydroxyquinoline aluminium salt
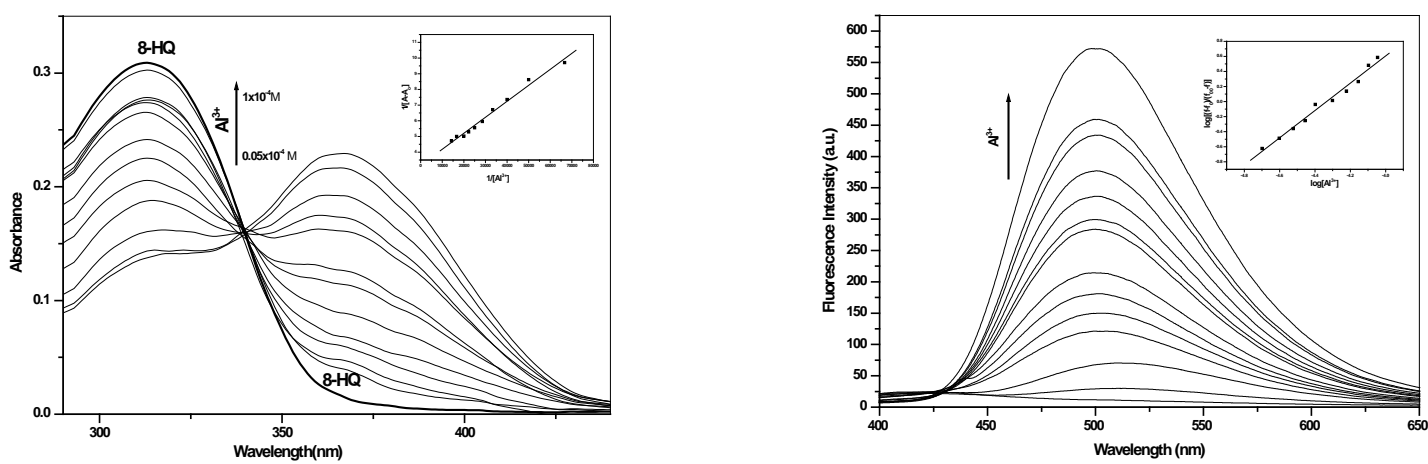

Figures 3 and 4. The effect of $\mathrm{Al}^{3+}$ ions on the absorption and fluorescencespectra of 8-HQ. The insertions forthe determination of the formation constantsof the complex
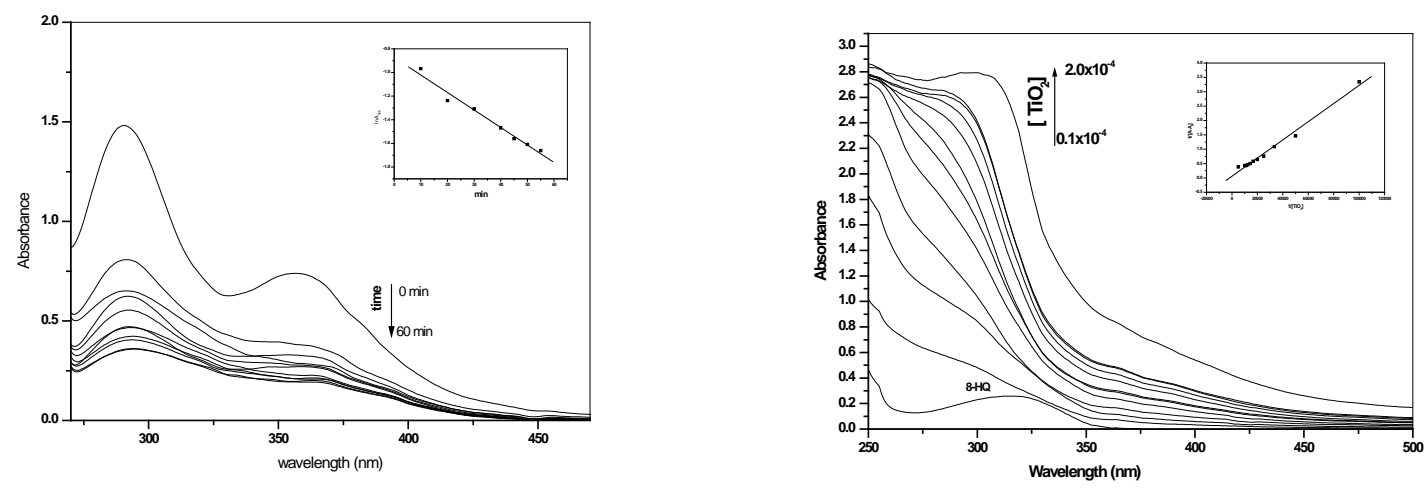

Fig.5. The effect of irradiation on the absorption spectrum of the surface complex in the presence of $\left(\mathrm{I}^{-} / \mathbf{I}_{2}\right)$ electrolyte solution. The insertion is the ratw constant of the reaction $\left(\mathbf{k}=0.015 \mathrm{~min}^{-1}\right)$

Fig.6. The effect of colloidal $\mathrm{TiO}_{2}$ on the absorption spectrum 8-HQ. The insertion is the apparent association constant $\left(\mathrm{K}=1 \times 10^{5} \mathrm{M}\right)$ 


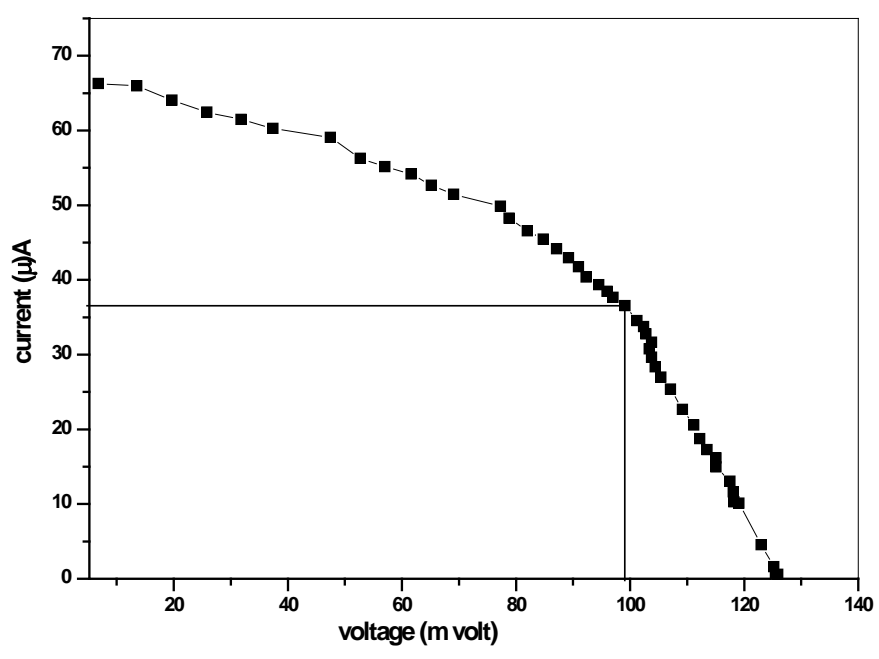

Fig.7.Current-voltagecurve for illumin-ated8-HQ solar cell 